\title{
Viral marketing: a powerful, but dangerous marketing tool
}

\author{
H.B. Klopper \\ Department of Business Management \\ Rand Afrikaans University \\ hbk@eb.rau.ac.za
}

\section{Contents}

1. Introduction

2. Goal and methodology of the research

3. Concept of viral marketing

4. Practice of viral marketing

5. Models to analyse viral marketing

6. Elements of viral marketing

7. Research findings

8. Implications for management

9. References

\section{Introduction}

Marketers have been using electronic tools for many years, but the Internet and other new technologies created a flood of interesting and innovative ways to provide and enhance customer value. Not only did this challenge the fundamental basics of traditional marketing, but it also helped to shape the practice of modern marketing. Coupled with the fact that the rate at which change takes place (as fuelled by technology) will not slow down, but accelerate, the biggest challenge facing local marketers will be to become globally competitive in terms of marketing efficiencies (Pretorius 2000:74). Bearing in mind that the big advances in business came from the early recognition of doing things in new ways, marketers should realize that new technologies can quickly create not only new markets, but also new ways to satisfy those markets (Perreault and McCarthy 2000:86). Doyle (1998:251) is convinced that how and where marketing functions are radically changing and he therefore supports the fact that marketers must change their ways of marketing, based on changes in the environment. One such change that must be exploited is that of viral marketing. Owing to increased competition and in an effort to stand out from the crowd, many businesses are now turning towards viral marketing (Wilding 2001:1). 
The advancement of technology has not only created new ways for marketers to spread information, but also enabled consumers to spread information on-line or through other digital mediums that challenge traditional marketing practices. Since viral marketing is still a new and unexplored concept for most South African marketers, it is the purpose of this article to determine if it is not just another buzzword. To establish if marketers can practise viral marketing, the concept of viral marketing is clarified before addressing more specific issues related to it.

The research was based on a literature study, but published material that explained the concept of viral marketing was limited. However, many examples were found. The collected information was interpreted and evaluated on a qualitative basis. In this article, the collected information is described arguments and recommendations of mainly the author are posed. Where possible, the author's views are supported by research found mainly on the Internet.

The results could provide South African marketers of an understanding of the concept of viral marketing, thus enabling them to use sound marketing principles to fully exploit this method, which may be a powerful but potentially dangerous marketing tool.

\section{Concept of viral marketing}

Wilson (2000:1) describes viral marketing as any strategy that encourages individuals to pass on a marketing message to others, thus creating the potential for exponential growth in the exposure and influence of the message. In Viral Marketing Online (2001,) it is explained that viral marketing is any advertising that propagates itself in the same way as viruses. The only difference is that viral marketing uses digital media. Therefore, the concept refers to a message that spreads to other people because the first recipient liked it and chose to send the message on to others, using what some people prefer to call 'word-of-mouse' communication (Hendrix 1999:31). This is the equivalent of word-of-mouth communication in off-line marketing. Less familiar ways of referring to viral marketing include referral marketing (Fanous-Samaan 1999:29), organic marketing (Viral Marketers Online 2001) or even network marketing (Wilson 2000:1).

Historically, many on-line viral marketing activities were generated more by accident than by design and, as with so many activities on the Internet, the theory appears to have developed after the practice. Indeed, the better known viral successes have required good business people to spot and develop the activity, rather than initiating it (Wilding 2001:1).

Many people mistakenly think viral marketing happens only through e-mail. Effectively, the user does the selling through an on-line mechanism, nearly always e-mail (Nucifora 2001:27; Bannan 2002:20; Rasmusson 2000:18), but it can also be transferred to other digital media of the Web such as graphics (Daniels 2001:12), software downloads and screen savers (personal interview with Chettoa 2001), short video clips (Lamirand 2000:51) and messages

distributed by mobile phones (Wallace 2000:12), to list only a few. A recent White Paper on viral marketing (Intrapromote 2001:2) named these self-contained objects (which are indeed independent of Web sites) 'viral objects'. Viral objects can be defined as something given to target users to pass along, something upon which the blinding force of the Internet, for example, can turn on. It can therefore be concluded that viral objects, provided by media such as Web sites or mobile phones, spread messages and not the medium itself. The medium is therefore the means to an end. With this as background, it is evident that the term 'word-of-mouse' is not a true definition of the concept of viral marketing, since messages that are distributed through media such as mobile phones are excluded. Although viral marketing may have a negative connotation (due to the negative connotations to the word 'viral'), it 
probably defines the concept the best because of the way in which messages are distributed.

Viral marketing capitalizes on the basic nature of multilevel marketing (MLM) and applies it to all customers, making every customer a salesperson (Horizon Marketing Online 2001). In a sense, viral marketing draws on what is sometimes known as Metcalfe's law, which states that the utility of a network is proportional to the squared numbers of users. As more people join the system (or start using a particular networked product), the number of cross-network connections rises not linearly with the users, but quadratically (Wind and Mahajan 2001:31). The above phenomenon probably best clarifies the term viral marketing, because the pattern of communication reflects the pattern with which an especially contagious virus can move through a set of interacting hosts (Coupey 2001:99).

With the above as background, it can be said that viral marketing is in a way just another buzzword for word-of-mouth marketing. The only major difference is the medium being used and the potential explosion in growth it promises. However, owing to the nature and opportunities provided by digital media such as the Internet and mobile phones, as well as the multiplier effect, it is worthwhile to explore viral marketing. In the rest of this article a few aspects with regard to viral marketing that marketers must take note of are highlighted.

\section{Practice of viral marketing}

Ironically enough, according to Ward (2000:26) and Wilding (2001:1), marketers can never purposely create a viral campaign that has even a fraction of the success that unplanned spreading has. This is because viral marketing is more about serendipity than planning, just as in the case of word-of-mouth marketing. Therefore, it is important to realize that one cannot engineer viral marketing. Ward notes that one can try to create a message worthy of passing along, but seeding the message and what happens after seeding are two very different things. The standpoint of this discussion is therefore based on the fact that marketers can create messages, but cannot determine their distribution spread. This, however, cannot exclude the fact that marketers can, through careful selection, determine to whom initial messages must be targeted, bearing in mind that what happens with the messages afterwards cannot be influenced.

Viral objects become true viral objects the moment a person forwards it to someone else. According to Intrapromote (2001:4), viral objects must be designed to appeal specifically and uniquely to a target market. The key is to introduce these viral objects into digital networks in a manner unlike spam. Viral objects should be in line with the digital spirit of sharing items of particular affinity within a given community, for example a contribution to an ongoing discussion in an on-line forum. It should not be an unwanted interruption, which is the case with most advertising.

Rasmusson (2000:18) is convinced that the success of viral marketing is tied to three things, namely (a) the nature of the company's industry; (b) the on-line tenure of the audience; and (c) the topic of the message. Marketers must realize that viral marketing is a digital phenomenon that cannot be created with an analogue strategy, due to the method through which the message is spread (Intrapromote). Viral marketing is extremely attractive to startup ventures with a limited marketing budget, since it costs very little but still delivers astounding results in a very short period (Nucifora 2000:27). Azeez (2001:1) states: 'Fundamentally, advertising and marketing budgets no longer stretch as far as they used to, and the perceived savings by going viral are too attractive to ignore.' Many marketers therefore try to implement viral marketing 'campaigns', but fail to realize that one can only influence the message and determine to whom it should be delivered initially. Also, viral 
marketing can have a reverse effect. Recipients of e-mail perceived as spam (a pejorative reference for unsolicited e-mail) can vent their opposition to thousands of users in public newsgroup forums and friends on e-mail lists, thereby quickly generating negative publicity for the organization. Marketers must therefore realize that unsolicited e-mail, a good example of what is perceived as a viral marketing campaign, shifts the burden of selectivity from sender to recipient. However, Strauss and Frost (2001:257) point out that marketers should remember that all unsolicited e-mail is considered spam but, just as with direct mail, when the e-mail is appropriate and useful to the recipient it is welcomed, unsolicited or not.

According to Fanous-Samaan (1999:29), another potential downside of viral marketing is the possibility to alter the content of the message before it is passed on. Viral marketing therefore works best with fixed content (for example software downloads) than with written messages where the recipient can easily modify the content.

Fadhley (2000:15) stresses that viral marketing can only be successful if the benefit of receiving a communication message is significantly greater than the nuisance or cost of passing it on. According to Daniels (2001:12), the challenge for marketers is to make their marketing messages interesting enough for people to want to spread it. A carefully designed viral marketing 'strategy', where people can spread information easily, could ripple out rapidly once it has been jump-started, as supported by Metcalfe's law.

One obvious problem with viral marketing is that it appears to be an open invitation to spammers. Therefore, according to Wallace (2000:12), credibility becomes even more of a factor given the current public mistrust in unsolicited e-mail. However, Bannan (2000:20) confirms that viral marketing has the inherent benefit of the recipient recognizing the name of the person who forwarded the message. Owing to this reason, it is increasingly common for opt-in lists to remind users that they are not being spammed. This is done by including a disclaimer at the beginning of the message that reminds recipients that they are receiving the message because of an earlier request to be notified. Besides this, marketers must remember that their messages must also contain an option for users to be removed from the list (optout). Only after this can viral marketing really come to life. True viral marketing only starts when consumers spread the message on their own.

\section{Models to analyse viral marketing}

As with everything else, hindsight is perfect sight. By evaluating successful viral marketing, evidence suggests that viral marketing works when it is specific and free. Besides these two qualities, all viral marketing 'campaigns' are based on one of three models namely the promotions model, the incentive-based model and the loyalty-based model.

In the experience of Wilding (2001:2), jokes, games and competitions rank highest in the viral marketing stakes. These fall into a category of viral marketing that, for argument's sake, can be called the promotions model. This model creates enough interest that consumers are willing to pass along the content to their friends, without receiving any incentives for doing so. According to Wilding, the trick is that the content must in some way enhance or demonstrate the personality of the sender or match the personality of the receiver so closely that the sender is compelled to bring it to his or her attention. Alternatively, it must be funny.

With incentive-based models, the sender is rewarded for his or her actions. According to Wilding (2001:2), this model will increasingly become the most common and probably most contentious one, given that the recipient is merely a component in a money-making mechanism. The saving grace thus far has been that monetary rewards are rare. This is unsurprising, considering the vast size of digital media and the difficulty of making 
payments. Instead, incentive-based viral marketing models involve some kind of reward scheme, for instance free products or 'Web currency'.

From a business point of view, a more controlled method is the loyalty-based model that combines elements of affiliate programmes and gives financial rewards, but only when the recipient engages in some way (Wilding 2001:2).

The underlying concept behind viral marketing is that people will interact with other people, spreading information about products or services. The spread of information by parties other than the organization can convey to potential customers what a product or service can be like. The only difference is the source of origin. Therefore, although consumers receive incentives to spread messages, it can be considered as a form of viral marketing because it is still the consumer who chooses the next recipients of the message or viral object.

\section{Elements of viral marketing}

Marketers attempting a viral marketing campaign must measure the effort of the campaign by setting targets for it and taking solid baseline reports before starting it. Rasmusson (2000:18) stresses the importance of making sure that any viral marketing campaign is integrated with other marketing efforts. According to Wilson (2000:2), an effective viral marketing strategy comprises six characteristics, namely:

- It gives away products or services for free. Although 'cheap' or 'inexpensive' may generate a wave of interest, 'free' will usually accomplish it much faster. The logic behind this is that 'free' attracts eyeballs, which in turn see desirable things that are purchased in most cases. Therefore, preferably give something away

- It provides for effortless transfer to others. From a marketing standpoint, it is important to simplify the message so it can be transmitted easily and without degradation

- It scales easily from small to very large. To spread like wildfire, the transmission method must be rapidly scalable from small to large. Marketers must realize that if the virus multiplies only to kill the host before spreading, nothing is accomplished. Marketers must therefore take care that servers, for instance, can be expanded quickly

- It exploits common motivations and behaviours. Greed can drive people; so can the need to be popular, loved and understood. The resulting urge to communicate produces millions of Web sites and billions of e-mail or other electronic messages. Therefore, clever viral marketing strategies take advantage of common human motivations and behaviours

- It uses existing communication networks. Throughout history, people have formed communities in which networks of human interaction convey social values, daily events and plans for activities that foster the well-being of the individual within the community and the community within the larger environment. Marketers must learn to place messages within the communications that exist between people, because people in digital environments also develop networks of relationships. By exploiting these networks, marketers can easily spread messages in an even cheaper way

- It takes advantage of other resources to get the word out. Affiliate programmes, for example, place text or graphic links on other people's or organizations' Web sites. The 
moment someone else's Web site is relaying your marketing message, someone else's resources are depleted instead of your own.

According to Wilson (2000:3), all successful viral marketing strategies use most of the six principles as outlined above. Probably the best way marketers can 'go viral' with their current offer is to use a separate product that forces everyone who comes in contact with it to turn to the product or service the marketer is trying to sell. The Pro Shop, for instance, uses a screensaver that one can download for free to spread their brand. This is a good example of successful viral marketing in South Africa, since many golfers have downloaded the screensaver without a single effort from The Pro Shop to promote it (personal interview with Chettoa 2001). The Pro Shop only created a link on their Web site where one can download the screensaver for free.

\section{Research findings}

It seems that viral marketing is an old idea (nothing else than word-of-mouth) that has been greatly revitalized by the speed and agility of digital resources, including the Web and mobile phones. However, marketers must realize that these digital means provide a way to do better, faster and sometimes even cheaper word-of-mouth marketing than could ever have been done before. Viral marketing is probably the best definition for the concept and, in a way, can be considered a new buzzword. It is important for marketers to realize the potential of viral marketing compared to word-of-mouth. Integrated properly with traditional marketing techniques, viral marketing definitely is a concept marketers must explore.

It is important for marketers to realize that viral marketing is a double-edged sword, since the word it spreads can be either positive or negative, depending on the situation. While viral marketing is one of the fastest growing segments of digital marketing, tracking results can be problematic and costly. Obviously, if one cannot track the results of a campaign, it is useless. Still, the potential reward of viral marketing is so much bigger than word-of-mouth marketing that it cannot even be compared. Viral marketing is a powerful theory, taking the principle of permission marketing to an extreme. It attempts to harness the strongest of all consumer triggers - the personal recommendation. In the digital age, it might well be possible to include consumers in marketing and let them spread the word to millions around the world. However, companies that pursue this tactic should remember that it is no miracle cure for their marketing ills. At best, it is a way to support a broad marketing programme. At worst, it is an awful little bug spread by desperate marketers and their unsuspecting consumers.

\section{Implications for management}

Now is the time for marketers to return to their traditional roots and rely on well-grounded strategy. To survive, it is crucial that South African marketers take the new rules and tools of the electronic age and apply sound marketing practices to them. In essence, viral marketing is to the virtual world what word-of-mouth is to the real world. However, since the digital mediums are radical catalysts for marketing transformation, new marketing skills and ways of doing are required. Marketers must, however, realize that moving beyond the basics does not mean side-stepping the basics. Viral marketing, although something new in a different environment, is nothing else than word-of-mouth.

As technology in our homes and offices get better, more creative minds are producing viral 
objects. Therefore, marketers will have to demonstrate caution in the future. For example, as more e-mails make their way into consumers' inboxes, the chance increases that commercial e-mail, including opt-in marketing, will be viewed as spam.

Viral marketing, which may look like an unpleasant or unlikely metaphor at first (owing to the negative connotation of 'infectious'), will probably take a few years to win acceptance in the South African market, due to the nature of digital usage in the country. It will, however, be essential to the success of many new organizations, due to its low cost and multiplier effect, if it is managed properly.

Has the time not come for marketers to ask themselves if they can really control viral marketing? Are marketers not just people influencing viral marketing? If so, it would be more accurate to assume that consumers are in control of viral marketing. What then is the difference between viral marketing and word-of-mouth? The only difference seems to be the effectiveness of the medium, since messages can spread faster, more effectively and to more people through digital media than through traditional off-line media. Based on the above, marketers are urged to turn to the roots of marketing, using sound marketing principles and practices, instead of jumping on the bandwagon of just another buzzword. Marketers must rather focus their efforts on what they do and how they do it. Consumers will still spread messages themselves, whether it is called word-of-mouth or viral marketing.

\section{References}

Azeez, W. 2001. Will viral marketing become an epidemic? New Media Age. [Online]. Available WWW: http://www.infotrac.london.galegroup.com.

Banna, K.J. 2000. It's catching (viral marketing). Mediaweek 10(23):20. [Online]. Available WWW: http://www.infotrac.london.galegroup.com.

Coupey, E. 2001. Marketing and the Internet: conceptual foundations. Upper Saddle River, New Jersey: Prentice-Hall.

Daniels, J. 2001. Viral marketing: how to achieve your objectives. Marketing Mix 19(6): 12.

Doyle, P. 1998. Looking to the future: marketing in the twenty-first century. In The CIM handbook of strategic marketing. Oxford: Butterworth-Heinemann.

Fadhley, S. 2000. Viral marketing well set for a bright future. Precision Marketing 412 (49):15. [Online].

Available WWW: http://www.infotrac.london.galegroup.com.

Fanous-Samaan, S. 1999. Viral marketing spread the messages with entertainment. Tampa Bay Business Journal 19(51):29. [Online]

Available WWW: http://www.infotrac.london.galegroup.com.

Hendrix, P.E. 1999. Built it, and they will come. Marketing Management (Winter):31-35.

Horizon Marketing Online. 2001. V-Marketing. [Online].

Available WWW: http://www.horizonmarketing.com/emarketing/main-vmarketing.html

Intrapromote. 2001. White paper: a viral marketing tutorial. [Online].

Available WWW: http://www.intrapromote.com 
Lamirand, R. 2000. Psst! Pass it on. BC Business 28(5):51. [Online].

Available WWW: http://www.infotrac.london.galegroup.com.

Nucifora, A. 2000. Find success with free 'word-of-net' marketing. Orlando Business Journal 17(4):27. [Online].

Available WWW: http://www.infotrac.london.galegroup.com.

Perreault, W.D. and McCarthy, E. J. 2000. Essentials of marketing: a global-managerial approach. 8th Edition. Boston: Irwin McGraw-Hill.

Personal communication. 2001. Interview with Chettoa, S, Group Internet Manager of The Pro Shop.

Pretorius, B. 2000. The future according to ... Brand Pretorius. Future 1(5):73-75.

Rasmusson, E. 2000. Viral marketing: healthier than it sounds. Sales and Marketing Management 152(6):18. [Online]

Available WWW: http://www.infotrac.london.galegroup.com.

Strauss, J. and Frost, R. 2001. E-marketing. 2nd Ed. Upper Saddle River, New Jersey: Prentice-Hall.

Viral Marketers Online 2001. Fellow viral marketers! [Online].

Available WWW: http://www.viralmarketer.com.

Wallace, A. 2000. The viral phase is upon us. Precision Marketing 12(45):12. [Online]. Available WWW: http://www.infotrac.london.galegroup.com.

Ward, E. 2000. Viral marketing involves serendipity, not planning. B to B Vol. 85:26. Online].

Available WWW: http://www.infotrac.london.galegroup.com

Wilding, M. 2001. Word of mouse. Business 2.0 - UK (February 6): 1-2. [Online]. Available WWW: http://www.business2.com/articles/Web/0,1653,16444,FF.html.

Wilson, R.F. 2000. The six simple principles of viral marketing. Web Marketing Today (70):1-4. [Online].

Available WWW: http://www.jrlenterprises.com/viral-marketing.htm

Wind, J. and Mahajan, V. 2001. Digital marketing: global strategies from the world's leading experts. New York: John Wiley.

\section{Disclaimer}

Articles published in SAJIM are the opinions of the authors and do not necessarily reflect the opinion of the Editor, Board, Publisher, Webmaster or the Rand Afrikaans University. The user hereby waives any claim he/she/they may have or acquire against the publisher, its suppliers, licensees and sub licensees and indemnifies all said persons from any claims, lawsuits, proceedings, costs, special, incidental, consequential or indirect damages, including damages for loss of profits, loss of business or downtime arising out of or relating to the user's use of the Website. 
$\checkmark$ I 
ISSN 1560-683X

Published by InterWord Communications for the Centre for Research in Web-based Applications, Rand Afrikaans University 